\title{
SUPPORT SYSTEM KELUARGA DENGAN KUALITAS HIDUP PASIEN KANKER DI YAYASAN KANKER INDONESIA SURABAYA
}

\author{
*Ni Putu Widari, **Putri Maulana Serlinda \\ STIKES William Booth Surabaya, Jl. Cimanuk No 20 Surabaya Telp. 031-5633365 Email: \\ stikes_williambooth@ymail.com
}

\begin{abstract}
ABSTRAK
Kanker merupakan salah satu penyakit yang dapat mempengaruhi perubahan kualitas hidup penderitanya baik kearah yang positif maupun negatif. Perubahan yang cenderung ke arah negatif dapat diminimalkan dengan adanya support system dari keluarga yang berupa dukungan instrumental, dukungan emosional, dukungan informasional, dan dukungan penilaian, dimana apabila penderita tidak mendapatkan support system dari keluarga akan berpengaruh pada kualitas hidupnya. Desain penelitian yang digunakan adalah korelasi dengan pendekatan cross sectional, yang bertujuan untuk menganalisis hubungan support system keluarga dengan kualitas hidup pasien Kanker. Variabel independen dalam penelitian ini yaitu support system keluarga dan variabel dependen yaitu kualitas hidup pasien Kanker. Populasi pada penelitian ini yaitu pasien Kanker di Yayasan Kanker Indonesia Surabaya berjumlah 20 responden, dengan sampel 19 responden yang dipilih melalui tekhnik probability sampling dengan pendekatan simple random sampling. Pengumpulan data dengan kuesioner support system keluarga dan kulitas hidup. Hasil penelitian menunjukan support systemkeluarga baik sebanyak 13 orang $(68,4 \%)$ dan kualitas hidup sedang sebanyak 10 orang (52,6\%). Analisa data menggunakan uji statistik Nonparametric Correlations dengan Spearmandan diperoleh tingkat signifikan 0,231 ( $\mathrm{p}>0,05)$, dengan demikian $\mathrm{H}_{0}$ diterima yang berarti tidak ada hubungan antara support system keluarga dengan kualitas hidup pasien kanker di Yayasan Kanker Indonesia Surabaya. Hal ini dapat disebabkan karena kurangnya motivasi dari dalam penderita kanker sendiri serta adanya dukungan dari sesama penderita kanker, dengan diberikannya support system yang baik diharapkan mampu meningkatkan kualitas hidup dari penderita kanker.
\end{abstract}

Kata Kunci : Support System Keluarga, Kualitas Hidup, Kanker

\begin{abstract}
Cancer is one disease that can affect the life quality of the sufferer towards either positive or negative. Changes that tend towards the negative can be minimized by having a support system from family in the form of instrumental support, emotional support, informational support, and appreciation support, where if the sufferer does not get a support system of family will affect the quality of life. The research design used correlation research with cross sectionalapproach, which analyzed the relationship between family support system with quality of life patients with Cancer. The independent variabel is family support system and dependet variable is quality of life patients with Cancer. The population of this research were patients Cancer in Yayasan Kanker Indonesia Surabaya 20 respondents and sample 19 respondents chosen by probability sampling technique with simple random sampling approach. Data were taken a questionnare family support system and quality of life. The result of this research indicated family support system for patients was good as many 13 people $(68,4 \%)$ and quality of life was moderate as many as 10 people $(52,6 \%)$. Analyzed data statical nonparametric correlations with spearman and obtained a significant level 0,231 ( $>0,05)$, hence $\mathrm{H}_{0}$ is accepted which means there is no relationship between family support system with life quality of Cancer patients in Yayasan Kanker Indonesia Surabaya. It can be caused because of a lack of motivation from his own cancer survivor as well as an endorsement from fellow cancer survivors, with a good support system for which it is expected to improve the life quality of cancer patients.
\end{abstract}

Key Word : Family Support System, Quality Of Life, Cancer. 


\section{PENDAHULUAN}

Kesehatan merupakan hal yang sangat penting bagi setiap orang untuk melakukan aktivitas dan berusaha memenuhi kebutuhannya. Sehat merupakan kesejahteraan di segala dimensi yaitu fisik, mental dan sosial, akan tetapi saat ini seiring dengan berkembangnya zaman dan perubahan pola hidup muncul berbagai masalah dalam kesehatan yang dapat mengancam kesehatan. Ancaman kesehatan dapat berupa penyakit menular maupun penyakit tidak menular, bersifat tidak kronis maupun kronis, salah satunya adalah kanker.

Kanker adalah suatu keadaan dimana terjadinya pertumbuhan sel sel yang tidak tidak normal dari jaringan tubuh yang merubah bentu menjadi pertumbuhan sel kanker. Pada pertumbuhan dan perkembangannya sel-sel tersebut memperluas pertumbuhannya ke bagian jaringan tubuh yang lain. hal tersebut dapat merusak jaringan tubuh sehingga dapat mengakibatkan terjadinya kematian pada sesorang. Pada masyarakat awam bpertumbuhan sel ganas ini sering disebut dengan kanker, namun oleh sebagian orang kanker sering di samakan dengan tumor. Kanker sering dikenal oleh masyarakat sebagai tumor, padahal tidak semua tumor adalah kanker. Penyakit Kanker dapat dapat terjadi pada semua orang dan pada semua tingkatan usia dan dapat terjadi pada bagian anggota tubuh dan pada semua golongan usia. Pada umumnya penderita kanker tidak merasakan dan tidak mengalami keluhan penyakit, terlebih pada stadium awal. Keluhan akan dirasakan bila sudah memasuki tahap lanjut dan sudah mengalami penyebarluasan sel kanker. Kanker dapat timbul karena pertumbuhan tanpa hambatan dari sel-sel abnormal yang menyebabkan kerusakan atau mutasi di dalam hampir selalu lebih dari satu gen akibat rangsangan karsinogen (Jong de W, 2005).

Penderita kanker akan mengalami perubahan yang menyebabkan terjadinya berbagai macam gangguan dari segi jasmani, rohani, psikologi maupun emosional. Pengidap kanker menganggap dirinya akan cepat mati, karena diketahui bahwa kanker merupakan salah satu penyakit yang sulitdisembuhkansehingga penderita kanker merasa jika dirinya tidak berguna, tidak berharga, depresi, putus asa, marah, gelisah, dan menunjukan perilaku agresif seperti marah dan berbicara kasar.Sikap dan pola pikir penderita kanker yang cenderung ke arah negatif dapat mempengaruhi kualitas hidup seseorang.

Kualitas hidup (Quality of Life) secara umum dapat di jelaskan sebagai suatu konsep dimana kemampuan seseorang untuk mendapatkan kehidupan yang normal yang berhubungan dengan anggapan seseorang secara individu tentang tujuan, harapan dan perhatian secara spesifik terhadap tatanan nilai dan budaya yang berhubungan dengan kehidupan atau keseharian yang dapat dipengaruhi oleh nilai dan budaya (Bramantoro T, 2016). Beberapa hal dapat meningkatkan kwalitas hidup dari penderita kanker diantara nya adalah dukungan kesehatan dan fungsi, dukungan sosial ekonomi, dukungan psikologis, dukungan spiritual, dan yang terpenting adalah dukungan dari keluarga. Dukungan keluarga bagi penderita kanker merupakan hal yang oleh ahli di katakan paling sangat mendukung kwalitas hidup pada penderita kanker. Dukunagn keluarga meliputi kebahagiaan keluarga, anak-anak, pasangan, dan kesehatan keluarga. Penderita kanker memiliki kualitas hidup dimensi fisik dan lingkungan berada pada tingkat rendah sedangkan kualitas dimensi hubungan sosial berada pada tingkat tinggi. Pada penderita kanker stadium lanjut memiliki kualitas hidup yang rendah pada dimensi psikologis karena tingkat spiritual yang rendah. Penurunan kualitas hidup pada penderita kanker juga dapat disebabkan karena penderita kanker merasa berada pada periode krisis sehingga membutuhkan penyesuaian.

Ketidakmampuan penderita memenuhi kebutuhannya dan melakukan perannya akan mengakibatkan penderita mengalami ketidakberdayaan atau putus asa. Ketidakberdayaan atau putus asa yang dialami oleh penderita kanker menurunkan kualitas hidupnya. Setiap penderita kanker akan membutuhkan penyesuaian yang berbeda bergantung pada persepsi, sikap, serta pengalaman pribadinya terkait dengan perubahan yang dialami. Selain itu, salah satu hal yang dibutuhkan oleh penderita kanker yaitu adanya dukungan atau suppport system yang dapat diberikan oleh keluarga.

Badan Organisasi Kesehatan Dunia (WHO) mengungkapkan, bahwa jumlah 
penderita kanker dari tahun ke tahun mengalami peningkatan, angka kesakitan akibat kanker di dunia pada tahun 2012 sekitar 14,1 juta dengan angka kematian 8,2 juta serta menyatakan bahwa Denmark merupakan negara dengan penderita Kanker terbanyak. Sedikitnya 326 dari 100.000 penduduk di negara tersebut menderita kanker (eprints.ums.ac.id).

Berdasarkan studi pendahuluan yang peneliti lakukan di Yayasan Kanker Indonesia Surabaya pada tanggal 10 Januari 2018 menunjukan bahwa terdapat sekitar 3035 penderita kanker yang tinggal di Yayasan Kanker Indonesiayang berasal dari seluruh Indonesia.Dari hasil wawancara dengan pengurus Yayasan Kanker Indonesia mengatakan bahwa kanker serviks merupakan jenis kanker terbanyak dengan rentang usia 20-60 tahun, selain itu pengurus Yayasan Kanker Indonesia juga mengatakan bahwa tidak semua penderita yang berada di tempat tersebut memiliki pendamping atau keluarga yang selalu menemani selama pengobatan. Saat penulis melakukan wawancara kepada ustad yang membantu untuk memberikan siraman rohani di Yayasan Kanker Indonesia mengatakan bahwa setiap malam saat ustad berjalan mengelilingi kamar penderita kanker terdengar bahwa penderita berkeinginan untuk mengakhiri hidupnya. Berdasarkan hasil wawancara yang dilakukan oleh penelitikepada7 orang penderita kanker, 3 penderita mengatakan selama pengobatan di RSUD Dr. Soetomo tidak didampingi oleh keluarga dengan alasan suami harus kerja dan tidak ada yang mengurus anak-anak dirumah, tetapi sering ada perasaan cemas, takut, khawatir, dan kondisi mengalami drop karena harus melakukan terapi yang membutuhkan waktu lama seorang diri sehingga penderita sering meminta bantuan kepada pendamping pasien lain untuk membantunya, namun pasien masih merasa bahwa keluarga memberi dukungan walaupun tidak selalu mendampingi pengobatan di Surabaya.Selain itu, peneliti juga melakukan pengamatan kepada 4 pasien yang tidak didampingi oleh keluarga, cenderung lebih banyak menghabiskan waktu di kamar dan saat ditanya alasannya kenapa tidak keluar kamar, pasien mengatakan bahwa dia tidak ada pendampingnya sehingga ia merasa berbeda dengan teman-temannya yang lain. Kanker yang menyerang seseorang mengakibatkan penderitanya mengalami perubahan fisik dan psikis karena harus menyesuaikan diri dengan kondisi yang baru dalam hidupnya. Perubahan fisik pada penderita kanker yaitu rambut rontok, penurunan berat badan, kehilangan nafsu makan, perubahan indra perasa dan penciuman, kelelahan, kulit dan bibir pucat, mual muntah, gangguan tidur dan konsentrasi yang buruk. Perubahan psikis yang terjadi pada penderita kanker meliputi kecemasan, ketakutan, gelisah, mudah tersinggung, cepat marah, dan merasa tidak berharga. Selain itu pengobatan yang berlangsung lama memiliki efek kesakitan tinggi, membawa dalam kondisi lemah bahkan depresi. Hal tersebut mendorong penderita untuk menentukan sikap yang menggambarkan kualitas hidup dirinya sendiri. Prioritas utama pasien kanker adalah kualitas hidup dan bukan kesembuhan dari penyakitnya. Namun, tidak semua penderita kanker memiliki kualitas hidup yang baik, hal itu disebabkan oleh berbagai faktor yaitu faktor internal dan faktor eksternal. Faktor internal yaitu faktor yang berasal dari dalam dirinya sendiri, sedangkan faktor ekternal yaitu berasal dari luar dirinya seperti tidak memperoleh dukungan dari orang terdekat yaitu keluarga sehingga penderita lebih cenderung memilih hidup yang singkat namun bahagia daripada hidup yang panjang tapi dengan banyak keterbatasan (Rosjidi I, 2010). Penurunan kualitas hidup yang tidak ditangani dapat mengakibatkan penderita kanker menarik diri dari lingkungan sosialnya, tidak berminat dalam melakukan aktivitas, emosi yang tidak stabil, harapan yang rendah, dan keputusasaan.

Berbagai upaya dapat dilakukan untuk membantu meningkatkan kualitas hidup penderita kanker yaitu dengan memberikan terapi konvensional. Terapi konvensional yaitu tindakan yang dilakukan untuk mengatasi penyakit kanker biasanya berupa pengobatan medis seperti kemoterapi, radiasi, pembedahan, dan terapi kombinasi (Aqila $\mathrm{S}$, 2013). Selain itu, hal yang tidak bisa diabaikan dalam meningkatkan kualitas hidup penderita kanker yaitu pemahaman akan kondisi psikis yang terjadi pada penderita penyakit kronis ini. Tindakan yang dapat diberikan secara menyeluruh untuk membantu mengurangi penderitaan penderita kanker yaitu dari segi psiko, sosio, kultural, 
dan spiritual. Tindakan tersebut dapat berupa dukungan seperi dukungan spiritual, dukungan sosial, dan dukungan yang diberikan oleh keluarga.Kehadiran orang terdekat yaitu keluarga diharapkan mampu membantu mengurangi beban dengan memberikan support kepada penderita.Support system atau sistem dukungan merupakan suatu hubungan sebagai wujud kepedulian dan perhatian dari sekelompok orang yang mana dapat memberikan motivasi kepada anggota yang lainnya agar bisa mengerjakan segala sesuatu secara optimal (Andarmoyo, 2012). Berdasarkan teori Hierarki kebutuhan yang dikemukakan oleh Abraham Maslow menyatakan bahwa setiap manusia memiliki lima kebutuhan dasar yaitu kebutuhan fisiologis, kebutuhan rasa aman dan perlindungan, kebutuhan rasa cinta, kebutuhan akan harga diri dan perasaan dihargai oleh orang lain serta kebutuhan aktualisasi diri. Teori Hierarki tersebut memiliki hubungan yang erat satu dengan yang lainnya dan setiap individu harus mencapai lima kebutuhan dasar tersebut. Kebutuhan akan rasa aman dan perlindungan serta rasa cinta didalam keluarga dalam memberikan kasih sayang, kepedulian, dan dukungan adalah hal yang paling utama dalam mencapai kualitas hidup yang lebih baik dan memperpanjang masa hidupnya. Jenis support atau dukungan dari keluarga yang dapat diberikan pada penderita kanker yaitu dukungan instrumental, dukungan informasional, dukungan penilaian, dan dukungan emosional. Dukungan informatif dapat berupa bantuan informasi yang disediakan agar dapat digunakan seseorang dalam mengatasi persoalan yang dihadapi. Dukungan emosional berupa ekspresi empati dan perhatian. Dukungan sosial emosional membuat sesorang merasa dimiliki dan dicintai pada saat stress. Dukungan sosial emosional dapat menurunkan tekanan psikologis yang dirasakan seperti kecemasan, gangguan umum dan depresi. Dukungan sosial yang diberikan akan memberikan manfaat yang sangat berguna pagi penderita kanker. Sedangkan dukungan penilaian merupakan penghargaan yang diberikan oleh seseorang atau keluarga kepada pihak lain dalam hal ini adalah penderita kanker yang di dasari pada kondisi sebenarnya dari penderita kanker (Setiadi, 2008).
Berdasarkan uraian diatas peneliti tertarik untuk melakukan penelitian tentang "Support System Keluarga Dengan Kualitas Hidup Pasien Kanker di Yayasan Kanker Indonesia Surabaya".

\section{BAHAN DAN METODE}

Desain penelitian yang digunakan sesuai tujuan penelitian adalah korelasi. Tujuan digunakan korelasi yaitu untuk menjelaskan suatu hubungan, memperkirakan, dan menguji berdasarkan teori (Nursalam, 2015). Pada penelitian ini untuk mengetahui hubungan antara support system keluarga dengan kualitas hidup pasien kanker berdasarkan pengambilan sampel dalam waktu yang bersamaan maka penulis menggunakan desain penelitian cross sectional. Cross sectional adalah mengungkapkan hubungan sebab akibat dengan cara melibatkan satu kelompok subjek karena mengambil sampel untuk paparan dan penyakit dalam waktu yang bersamaan (Nursalam, 2015). Berdasarkan tujuan penelitian menggunakan desain ini adalah agar peneliti dapat menilai hubungan support system keluarga dengan kualitas hidup pada pasien kanker. Variabel bebas (independent) dalam penelitian ini adalah support system keluarga. Variabel Terikat (Dependent) adalah kualitas hidup pada penderita Kanker. Populasi pada penelitian ini adalah semua penderita Kanker di Yayasan Kanker Indonesia Surabaya (berdasarkan data dari Yayasan Kanker Indonesia Surabaya). Sampel pada penelitian ini adalah sebagian pasien Kanker di Yayasan Kanker Indonesia Surabaya.Tekhnik sampling dalam penelitian ini adalah simple random samplingdimana sebelumnya nama responden telah diberi kode dari angka 1 hingga 20. Tehnik pengumpulan data Peneliti mengadakan pendekatan kepada responden untuk mendapatkan persetujuan sebagai responden dan menerima responden yang sesuai dengan kriteria penelitian, responden dipilih menggunakan probability sampling dimana setiap individu dalam populasi mempunyai kesempatan untuk terpilih atau tidak terpilih sebagai sampel. Responden yang terpilih berjumlah 19 orang diminta untuk menjadi responden dengan menandatangani surat permohonan responden serta diberi kuesioner dan diminta mengisi 
kuesioner tentang support system keluarga dan kualitas hidup.

\section{HASIL}

1. Karakteristik Responden Berdasarkan Usia

\section{Usia}

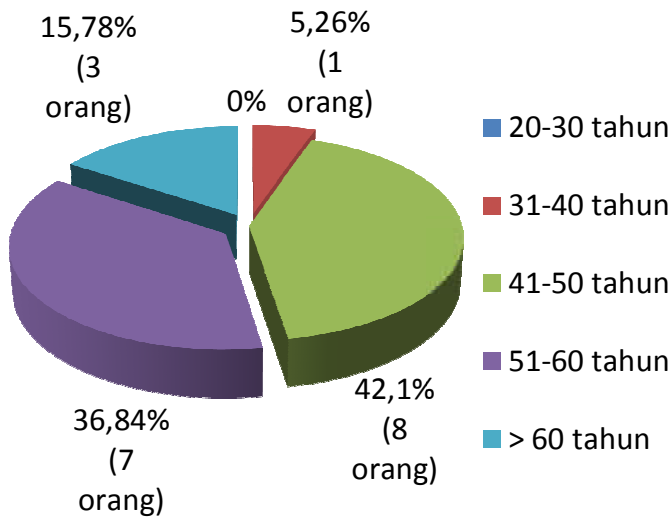

Gambar1 Diagram Pie Karakteristik Respoden Berdasarkan Usia di Yayasan Kanker Indonesia Surabaya April-Mei 2018.

Berdasarkan diagram pie 5.1 tampak bahwa sebagian besar yaitu 8 orang $(42,1 \%)$ responden berusia antara 41-50 tahun dan 1 orang $(5,26 \%)$ responden yang berusia 31-40 tahun.

2. Karakteristik Responden Berdasarkan Jenis Kelamin

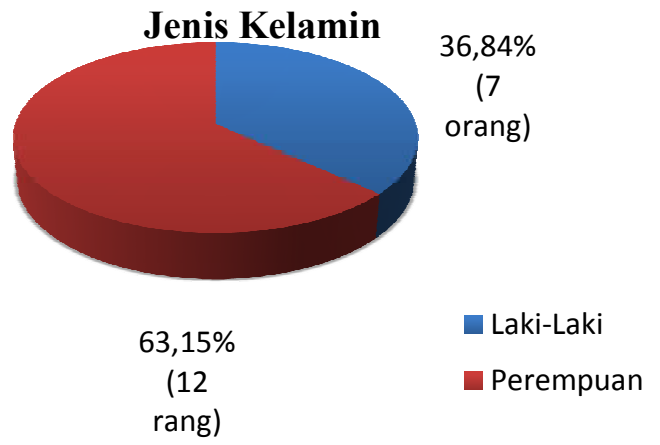

Berdasarkan diagram pie 5.2 tampak sebagian besar responden berjenis kelamin perempuan sebanyak 12 orang $(63,15 \%)$.
3. Karakteristik Responden Berdasarkan Tingkat Pendidikan

\section{Pendidikan}

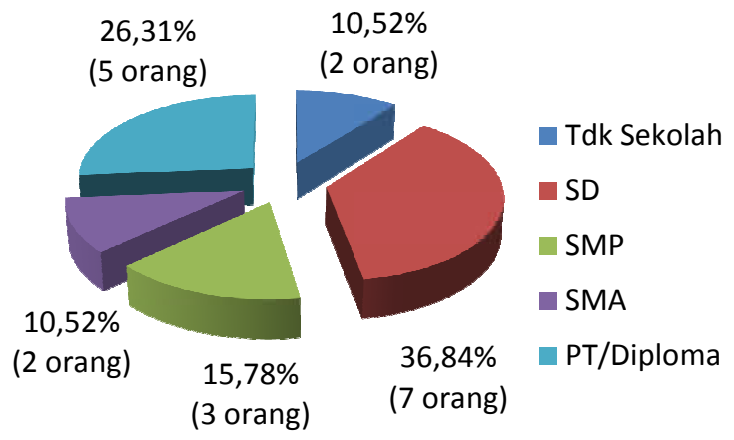

Gambar 3 Diagram Pie Karakteristik Responden Berdasarkan Pendidikan Terakhir di Yayasan Kanker Indonesia Surabaya April-Mei 2018.

Berdasarkan diagram pie 5.3 tampak sebagian besar responden yaitu sebanyak 7 orang $(36,84 \%)$ responden berpendidikan Sekolah Dasar (SD).

4. Karakteristik Responden Berdasarkan Status Pernikahan

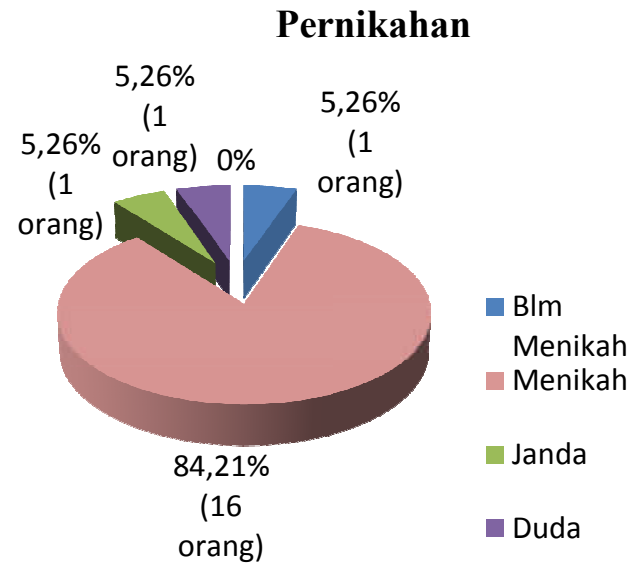

Gambar 4 Diagram Pie Karakteristik Responden Berdasarkan Status Pernikahan di Yayasan Kanker Indonesia Surabaya April-Mei 2018. 
Berdasarkan diagram pie 5.4 tampak sebagian besar responden yaitu sebanyak 16 orang $(84,21 \%)$ responden berstatus menikah dan 1 orang $(5,26 \%)$ berstattus janda serta duda.

5. Karakteristik Responden Berdasarkan Pekerjaan

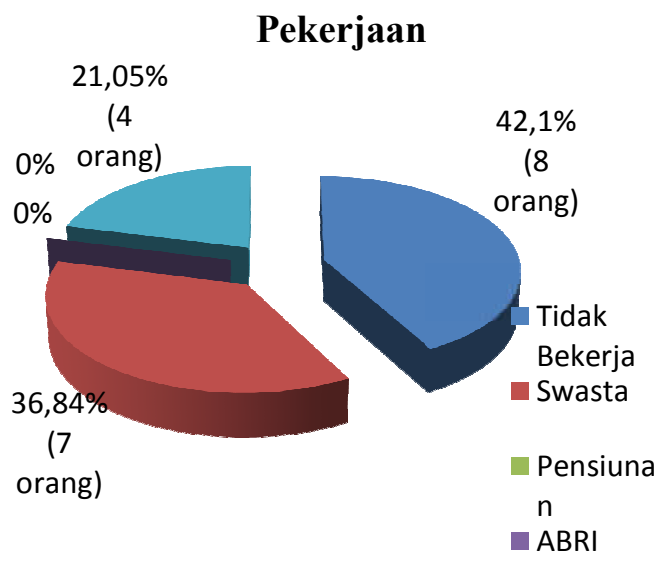

Gambar 5 Diagram Pie Karakteristik Responden Berdasarkan Pekerjaan di Yayasan Kanker Indonesia Surabaya April-Mei 2018.

Berdasarkan diagram pie 5.5 tampak paling banyak yaitu sebanyak 8 orang $(42,1 \%)$ responden tidak bekerja dan tidak ada responden yang bekerja sebagai pensiunan dan ABRI.

6. Karakteristik Responden Berdasarkan Kartu Jaminan Kesehatan

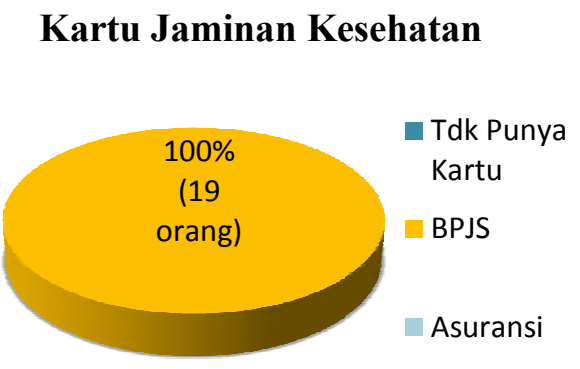

Berdasarkan diagram pie 6 sebagian besar sebanyak 19 orang (100\%) menggunakan kartu jaminan kesehatan.
7. Karakteristik Responden Berdasarkan Lama Menderita Sakit

\section{Lama Menderita Kanker}

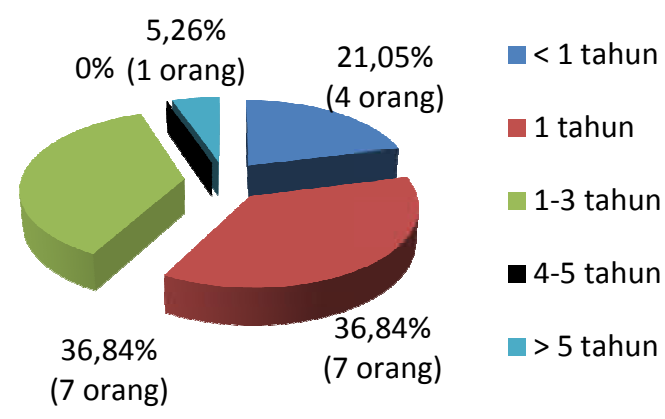

Gambar 7 Diagram Pie Karakteristik Responden Berdasarkan Lama Menderita Sakit.

Berdasarkan diagram pie 7 tampak sebagian besar yaitu sebanyak 7 orang $(36,84 \%)$ responden menderita sakit selama 1-3 tahun dan 1 orang $(5,26 \%)$ responden menderita sakit lebih dari 5 tahun.

8. Karakteristik Responden Berdasarkan Penghasilan

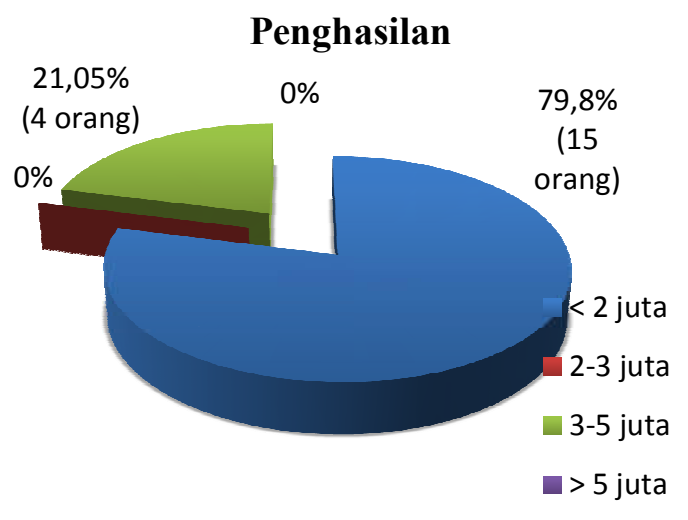

Gambar 8 Diagram Pie Karakteristik Responden Berdasarkan Penghasilan

Berdasarkan diagram pie 5.8 tampak sebagian besar yaitu sebanyak 15 orang $(78,9 \%)$ responden memiliki penghasilan 
$<2$ juta satu bulan dan 4 orang $(21,05 \%)$ responden yang memiliki penghasilan 3-5 juta dalam satu bulan.

\section{Data Khusus}

1. Support System Keluarga

Tabel 5.1 Distribusi frekuensi support system keluarga

\begin{tabular}{ccc}
\hline $\begin{array}{c}\text { Support } \\
\text { System }\end{array}$ & Frekuensi & Presentase \\
Keluarga & & \\
\hline Baik & 13 & 68,4 \\
Sedang & 5 & 26,3 \\
Buruk & 1 & 5,3 \\
Total & 19 & 100 \\
\hline
\end{tabular}

Berdasarkan tabel 1 dapat diketahui bahwa sebagian besar yaitu sebanyak 13 orang $(68,4 \%)$ responden mendapatkan support system keluarga yang baik dan hanya 1 orang $(5,3 \%)$ responden yang kurang mendapatkan support system keluarga.

2. Kualitas Hidup

Tabel 2 Distribusi frekuensi kualitas hidup dengan responden

\begin{tabular}{ccc}
\hline $\begin{array}{c}\text { Kualitas } \\
\text { Hidup }\end{array}$ & Frekuensi & Presentase \\
\hline Baik & 8 & 42,1 \\
Sedang & 10 & 52,6 \\
Buruk & 1 & 5,3 \\
Total & 19 & 100 \\
\hline
\end{tabular}

Berdasarkan tabel 2 dapat diketahui bahwa 8 orang $(52,6 \%)$ responden memiliki kualitas hidup baik dan hanya 1 orang $(5,3)$ responden yang mengalami kualitas hidup buruk.

3. Hubungan antara support system keluarga dengan kualitas hidup

Tabel 3 Tabel tabulasi silang antara support system keluarga dengan kualitas hidup responden

\begin{tabular}{llcccc}
\hline No & $\begin{array}{l}\text { Support } \\
\text { System } \\
\text { Keluarga }\end{array}$ & \multicolumn{4}{c}{ Kualitas Hidup } \\
Baik & Sedang Buruk & Jumlah \\
\hline 1 & Baik & 7 & 5 & 1 & 13 \\
& & $3,8 \%$ & $38,5 \%$ & $7,7 \%$ & $100 \%$ \\
\hline
\end{tabular}

\begin{tabular}{cccccc}
\hline 2 & Sedang & 1 & 4 & & 5 \\
& & $20 \%$ & $80 \%$ & - & $100 \%$ \\
3 & Buruk & & 1 & & 1 \\
& & - & 100 & - & $100 \%$ \\
& & & $\%$ & & \\
\multicolumn{2}{c}{$\begin{array}{c}\text { Jumlah } \\
\text { P }=0,231\end{array}$} & 8 & 10 & 1 & 19 \\
\hline
\end{tabular}

Dari tabulasi silang diatas tampak bahwa terdapat 7 orang responden $(53,8 \%)$ yang support system keluarga baik dengan kualitas hidup baik dan hanya 1 orang responden (100\%) yang memiliki support system buruk dengan kualitas hidup sedang. Dari hasil uji statistik spearman didapatkan hasil $\mathrm{P}=0,231$ dengan tingkat kemaknaan $\rho$ $>0,005$ yang berarti $\mathrm{H}_{0}$ diterima atau tidak ada hubungan secara signifikan antara support system keluarga dengan kualitas hidup pasien kanker di Yayasan Kanker Indonesia Surabaya.

\section{PEMBAHASAN}

Hubungan antara support system keluarga dengan kualitas hidup pada responden berdasarkan uji statistik spearman didapatkan nilai tidak signifikan $\mathrm{p}=0,231$ yang berarti $\mathrm{H}_{0}$ diterima atau tidak ada hubungan antara support system keluarga dengan kualitas hidup pasien kanker di Yayasan Kanker Indonesia Surabaya.Berdasarkantabel tabulasi silang 3 tentang support system keluarga dengan kualitas hidup pasien kanker dapat dilihat bahwa 1 orang $(7,7 \%)$ support system baik dengan kualitas hidup buruk dan 1 orang (100\%) support system buruk dengan kualitas hidup sedang.Menurut M Husni (2012) menyatakan bahwa ada hubungan yang signifikan antara support system keluarga dengan kualitas hidup pasien kanker. Penelitian ini tidak memiliki hubungan antara support system keluarga dengan kualitas hidup yang dapat disebabkan karena motivasi dari pasien untuk meningkatkan kualitas hidup masih kurang. Motivasi diri yang kurang disebabkan karena kurangnya dorongan yang dapat memicu timbulnya rasa semangat untuk sembuh dan melawan penyakit yang dideritanya. Motivasi diri yang kurang juga dapat disebabkan karena penderita kanker mengalami kondisi psikologis yang tidak menyenangkan, seperti cemas, takut, sedih, gelisah, merasa sendiri, atau dibayangi oleh kematian, serta merasa 
bahwa dirinya tidak berguna. Kecemasan dapat meningkat ketika penderita kanker membayangkan terjadinya perubahan dalam hidupnya di masa depan akibat penyakit yang diderita ataupun akibat dari proses penanganan suatu penyakit. Kadangkala proses penanganan suatu penyakit lebih membebani penderita dibandingkan dengan penyakit yang dideritanya, seperti proses radiasi, kemoterapi, serta konsumsi obatobatan yang digunakan untuk membunuh selsel kanker yang mengakibatkan kerusakan tubuh. Adanya perasaan negatif yang berlarut-larut dan tidak ditangani dapat menimbulkan munculnya stress, stress yang berkepanjangan juga dapat mengakibatkan munculnya perasaan kehilangan kontrol, penolakan terhadap kenyataan, serta depresi. Depresi yang dialami akan membuat penderita tidak bisa menerima keadaan dirinya sebagai orang yang sakit sehingga akan terus merasa bahwa dirinya adalah orang yang paling tidak beruntung sehingga berpengaruh pada kualitas hidupnya yang semakin menurun. Pada kondisi seperti ini, biasanya dukungan dari keluarga sudah tidak memberikan dampak yang berarti bagi penderita kanker karena dari dalam diri penderita sudah tidak memiliki motivasi untuk dapat sembuh dari penyakitnya.

Berdasarkan diagram pie 7 tentang karakteristik responden berdasarkan lama menderita sakit, tampak 7 orang $(36,84 \%)$ responden menderita sakit selama 1-3 tahun. Menurut teori Green (2005), menyatakan bahwa jika seseorang menderita penyakit lama, maka individu tersebut akan mempunyai pengalaman yang lama tentang penyakitnya. Seiring dengan berjalannya waktu dan penyakit yang relatif lama akan membuat penderita kanker mampu untuk beradaptasi dengan penyakitnya. Diketahui bahwa adaptasi yang baik dapat membantu penderita untuk lebih menerima kondisi maupun penyakit yang sedang dihadapi, hal ini akan berpengaruh pada psikologis penderita yang cederung memiliki pandangan positif. Pada kondisi seperti ini, penderita kanker cenderung lebih mandiri dibandingkan dengan saat awal menderita kanker sehingga tidak hanya dukungan keluarga yang dapat menjadi faktor untuk mempengaruhi kualitas hidupnya.

Selain itu, dukungan sosial yang didapatkan penderita kanker dari sesama penderita kanker dapat berpengaruh terhadap kualitas hidupnya. Menurut pendapat dari Hartanti (2002) menyatakan bahwa pasien yang sedang pada masa penyembuhan akan lebih cepat sembuh apabila mendapat dukungan yang berasal dari lingkungan sosial, seperti keluarga maupun teman yang sama-sama menderita sakit sehingga akan membuat penderita merasa diperhatikan dan tidak sendirian. Dukungan berupa semangat yang diberikan oleh sesama penderita kanker dan lingkungan sekitar dapat mempermudah penderita dalam beradaptasi dengan kondisinya sehingga penderita memiliki semangat tinggi untuk sembuh dari sakitnya. Penderita kanker yang ada di Yayasan Kanker Indonesia Surabaya biasanya saling sharing tentang penyakit, pengobatan yang dijalani, serta pengalaman hidupnya sehingga meski penderita tidak didampingi oleh keluarga hal tersebut tidak membuat penderita kehilangan rasa percaya diri, tetap memiliki keyakinan yang besar untuk dapat sembuh, serta tidak merasa sendirian karena penderita menganggap penderita yang lain seperti keluarga baru baginya. Sesama penderita kanker akan saling memberikan motivasi dan bantuan kepada penderita kanker lainnya dan hal ini akan memberikan dampak yang positif sehingga penderita menjadi lebih kuat, optimis, serta mampu bertahan melawan penyakitnya yang berpengaruh pada kesehatannya dan kualitas hidupnya.

\section{SIMPULAN}

Pasien kanker yang tinggal di Yayasan Kanker Indonesia Surabaya sebagian besar $68,4 \%$ memiliki support system keluarga yang baik.

Pasien kanker yang tinggal di Yayasan Kanker Indonesia Surabaya sebagian besar $52,6 \%$ memiliki kualitas hidup sedang.

Tidak ada hubungan antara support system keluarga dengan kualitas hidup pasien kanker di Yayasan Kanker Indonesia Surabaya.

\section{SARAN}

Hendaknya keluarga memberikan support atau dukungan baik secara moril maupun materi. Dukungan yang diberikan oleh keluarga akan memberikan dampak 
positif yang besar bagi penderita kanker, sehingga penderita akan merasa dicintai, disayangi, diperhatikan, tidak merasa sendirian, dan dapat menerima kondisinya sehingga kualitas hidup penderita kanker menjadi lebih baik.

Dengan adanya hasil penelitian tentang support system keluarga dengan kualitas hidup pasien kanker, diharapkan untuk dapat memotivasi keluarga penderita untuk dapat mendampingi pasien selama menjalani pengobatan di Rumah Sakit, selain itu diharapkan adanya tenaga medis yang membantu merawat pasien sehingga apabila kondisi pasien sewaktu-waktu mengalami penurunan dapat ditangani dengan cepat sebelum akhirnya dirujuk ke Rumah Sakit.

Dengan adanya hasil penelitian ini, diharapkan dapat menambah kepustakaan yang telah dimiliki perpustakaan STIKes William Booth Surabaya serta dapat dijadikan sebagai tambahan materi tentang support system keluarga dimana support atau dukungan yang diberikan oleh keluarga memberikan dampak positif bagi kesembuhan pasien.

Hasil penelitian ini dapat dijadikan pertimbangan bagi peneliti selanjutnya dengan cara yang berbeda sehingga hasilnya akan menjadi lebih baik.

\section{DAFTAR PUSTAKA}

Abdul, G. 2009. Cara Mudah Mengenal \& Mengobati Kanker. Jogjakarta : PN Flamingo.

Alam, S. 2017. Diunduh pada tanggal 23 Januari 2018 dalam respiratory.stikesayanyk.ac.id pukul 09.49 .

Alimul, A. 2004. Pengantar Konsep Dasar Keperawatan. Jakarta : PN Salemba Medika.

Aqila, S. 2013. Kanker Organ Reproduksi. Jogjakarta : PN A Plus Books.

Bramantoro, T. 2016. Kualitas Hidup Anak Usia Dini Terkait Kesehatan Gigi. Surabaya : PN Pusat Penerbitan dan Percetakan (AUP).

Dewi E, dkk. 2015. Kualitas Hidup Pasien Kanker. Diunduh pada tanggal 23 Januari 2018 dalam jurnal.unpad.ac.id pukul 09.48.

Hartanti. 2002.Psikoborneo 2016. Ejournal Psikologi Fisip 4 (4) : 829-837.
Jalu, N. 2010. Awas!!! Bahaya Kanker Rahim Dan Kanker Payudara, Mengenal, Mencegah Dan Mengobati Sejak Dini Dua Kanker Pembunuh Paling Ditakuti Wanita. Yogyakarta : PN PT Buku Kita.

Jong de W. 2005. Kanker Apakah Itu? Pengobatan, Harapan Hidup, Dan Dukungan Keluarga. Jakarta : PN Arcan.

Namora, L. 2009. Depresi. Jakarta : PN Kencana.

Nursalam. 2015. Metodologi Penelitian Ilmu Keperawatan : Pendekatan Praktis. Jakarta : PN Salemba Medika.

R Noviyanti. 2015. Uji Validitas dan Reliabilitas Kuesioner EORTC QLQ C30. Diunduh pada tanggal 23 Januari 2018 dalam jurnal.unpad.ac.id pukul 08.58

Rosjidi I. 2010. Perawatan Paliatif Suportif \& Bebas Nyeri Pada Kanker. Jakarta: PN CV Sagung Seto.

Sari, A. 2017. Diunduh pada tanggal 19 Januari 2018 dalam jiis.akfarisfibjm.ac.id pukul 08.05.

Setiadi. 2007. Konsep Dan Penulisan Riset Keperawatan. Yogyakarta : PN Graha Ilmu.

Tinartayu, S. 2015. Diunduh pada tanggal 18 Januari 2018 dalam journal.umy.ac.id pukul 20.30 .

S. Suhardin. 2015. ACT (Acceptance and Commitment Therapy). Diunduh pada tanggal 23 Januari 2018 dalam https://ejournal.unair.ac.idpukul 08.54.

Wawan, S. 2014. Kanker Deteksi Dini, Pengobatan dan Penyembuhannya. Yogyakarta : PN Parama Ilmu.

WR, Aprilia. 2014. Bab II Tinjauan Pustaka. Dalam respiratory-suska.ac.id.

Yellila, M. 2005. Cara Bijak Menaklukan Kanker. Jakarta : PN Agro Media Pustaka.

Yellila, M. 2009. Solusi Sehat Mencegah Dan Mengatasi Kanker. Jakarta : PN Agromedia Pustaka. 